\title{
PEMANFAATAN LABORATORIUM MAYA: PELUANG DAN TANTANGAN
}

\author{
The Utilization of Virtual Laboratory: \\ Opportunities and Challenges
}

\author{
Ahmad Ardius \\ SMP Negeri 1 Tanjung Batu, Jl. Merdeka KM.53 Tanjung Batu, \\ Kabupaten Ogan Ilir, \\ Provinsi Sumatera Selatan 30664 - Indonesia \\ ardiusf@yahoo.com
}

Diterima:

04 Oktober 2019, Direvisi:

13 November 2019, Disetujui:

20 Oktober 2020

\begin{abstract}
ABSTRAK: Pembelajaran sains di sekolah-sekolah telah berubah. Ada kemungkinan pembelajaran sains akan kehilangan makna menjadi sebuah pembelajaran sastra. Berdasarkan hasil pengamatan peneliti secara terbatas di sekolah terhadap guru-guru yang mengampu mata pelajaran sains, hanya $20 \%$ yang melaksanakan kegiatan praktikum; sedangkan $80 \%$ sisanya menyampaikan materi pembelajaran tanpa praktikum. Untuk mengatasi kendala ketiadaan perangkat laboratorium, kegiatan praktikum dapat dilakukan melalui Laboratorium Maya yang tersedia di Portal Rumah Belajar. Tujuan penelitian/kajian ini adalah untuk mengetahui peluang dan tantangan dari pemanfaatan Laboratorium Maya dalam proses kegiatan belajar-mengajar. Metode yang digunakan adalah studi literatur mengenai konsep dan teori melalui berbagai dokumen dan literatur yang tersedia. Data didapat dari sumber primer dan sekunder. Data dan informasi dianalisis melalui teknik analisis isi dan disajikan secara deskriptif. Penelitian mengungkapkan bahwa pemanfaatan Laboratorium Maya bisa mengatasi berbagai masalah yang dihadapi sekolah, seperti kegiatan praktikum untuk pembelajaran sains. Peluang pemanfaatan Laboratorium Maya antara lain mampu mengatasi berbagai keterbatasan yang berkaitan dengan waktu, kondisi geografis maupun ekonomis. Selain itu, Laboratorium Maya dapat meningkatkan kualitas eksperimen, efektivitas pembelajaran, keamanan, dan keselamatan. Kemungkinan tantangan pemanfaatan Laboratorium Maya antara lain meliputi ketersediaan perangkat komputer untuk kepentingan praktikum di sekolah, penguasaan guru dan siswa di bidang pengoperasian perangkat (penguasaan keterampilan motorik), ketersediaan sumber tenaga listrik, dan kesediaan/inisiatif guru untuk berinovasi memanfaatkan TIK di dalam aktivitas pembelajaran. Hasil analisis data menyimpulkan bahwa Laboratorium Maya sangat menjanjikan atau berpeluang untuk diterapkan pada kegiatan praktikum di sekolah. Tantangannya adalah kesediaan guru untuk berkontribusi memperkaya ketersediaan materi praktikum pada Laboratorium Maya yang terdapat pada Portal Rumah Belajar.
\end{abstract}

Kata Kunci: Laboratorium Maya, pembelajaran, peluang, tantangan 


\begin{abstract}
Science learning in schools has been changing. There is a possibility that science learning will lose its essential meaning, turning into a literature learning. Based on the result of the researcher's limited observation on science teachers at the school, only $20 \%$ of them carry out practicum, while the remaining $80 \%$ of them deliver learning materials without any practicum. To overcome the constraints of inavailability of laboratory equipment, practicum can be carried out through the Laboratorium Maya (Virtual Laboratory) which is available in the portal of Rumah Belajar. The objective of this study is to study the opportunities and challenges of utilizing Laboratorium Maya in the teaching-learning process. The method applied in this study is literature study on concepts and theories through a variety of available documents and literature. Data are obtained from primary and secondary sources. Data and information are analyzed through content analysis techniques and presented descriptively. The study reveals that the use of Laboratorium Maya can overcome various problems faced by schools, such as practicum for science learning. Opportunities for the use of Laboratorium Maya are able to overcome various constraints related to time, geographical as well as economic conditions. Besides, Laboratorium Maya can improve the quality of experiments, learning effectiveness, security, and safety. Possible challenges for the use of Laboratorium Maya are the availability of computers for practicum purposes in schools, the teachers and students' computer operating skill, the availability of power sources, and the willingness/ initiative of teachers to innovate in utilizing ICT for learning activities. The result of the data analysis shows that Laboratorium Maya is very promising, or in other words, it offers opportunities to be utilized in practicum in schools. The challenge is the teachers' willingness to contribute to the availability of practicum materials in Laboratorium Maya in the portal of Rumah Belajar.
\end{abstract}

Keywords: Laboratorium Maya, learning, opportunities, challenges

\title{
PENDAHULUAN
}

Pemerintah Indonesia melalui Kementerian Pendidikan dan Kebudayaan terus berupaya meningkatkan mutu pendidikan. Dalam kaitan ini, Kementerian Pendidikan dan Kebudayaan melalui Pusat Teknologi Informasi dan Komunikasi Pendidikan dan Kebudayaan (Pustekkom) terus berusaha menjadikan pendidikan di Indonesia setara dengan pendidikan di negara-negara berkembang lainnya. Pustekkom Kemendikbud kini telah beralih nama menjadi Pusat Data dan Teknologi Informasi (Pusdatin), Kementerian Pendidikan dan Kebudayaan. Salah satu upaya yang dilakukan adalah penyelenggaraan kegiatan pembelajaran melalui pemanfaatan Teknologi Informasi dan Komunikasi (TIK) yang dikenal dengan istilah e-learning. Dalam kaitan ini, Pusdatin telah mengembangkan sebuah portal pendidikan yang diberi nama portal Rumah Belajar.

Portal Rumah Belajar ini merupakan sebuah jawaban atas tantangan pendidikan revolusi industri 4.0 yang memiliki ciri utama yaitu siswa dan guru mampu memanfaatkan teknologi digital di dalam kegiatan pembelajaran. Artinya, transfer ilmu pengetahuan dapat dilakukan tidak hanya melalui kegiatan pembelajaran secara tatap muka (konvensional) tetapi juga melalui pemanfaatan TIK. Dalam kaitan ini, Pusdatin telah mengembangkan portal Rumah Belajar yang dapat diakses oleh siapa saja secara gratis. 
Salah satu fitur yang tersedia di portal Rumah Belajar adalah Laboratorium Maya (Virtual Laboratory) yang dapat dimanfaatkan, baik oleh guru maupun peserta didik, untuk melakukan kegiatan-kegiatan praktikum. Satu hal yang sangat menarik adalah tidak dibutuhkannya ruangan khusus secara fisik untuk melaksanakan kegiatan praktikum melalui Laboratorium Maya. Sangat berbeda halnya dengan laboratorium konvensional yang menuntut adanya ruangan khusus secara fisik dan perangkat instrumen serta bahan-bahan yang dibutuhkan untuk melaksanakan kegiatan praktikum, kegiatan praktikum melalui Laboratorium Maya dapat dilaksanakan kapan saja, di mana saja, dan oleh siapa saja dengan syarat ada koneksi internet.

Kurikulum 2013 merupakan penegasan atas pendekatan ilmiah dalam belajar sains. Pembelajaran sains menghendaki adanya eksperimen dan observasi untuk menguji teori atau hukum yang telah ada. Pendekatan ilmiah dalam pembelajaran sains dapat tercapai secara maksimal jika di dalam proses kegiatan pembelajaran dilakukan percobaan dan penelitian di laboratorium.

Laboratorium merupakan bagian integral dari kegiatan pembelajaran. Peranan kegiatan praktikum yang dilaksanakan di laboratorium adalah sangat penting untuk mencapai tujuan pembelajaran. Sebuah laboratorium harus dilengkapi dengan sarana dan prasarana kebutuhan percobaan sehingga tujuan dari laboratorium sebagai tempat kegiatan riset/ penelitian, percobaan, pengamatan, dan pengujian ilmiah bisa tercapai (Agustina, 2018).

Praktikum itu sendiri merupakan salah satu metode pembelajaran yang dapat menumbuh-kembangkan rasa ingin tahu peserta didik, aktif, kreatif, inovatif, dan kejujuran ilmiah dalam menghadapi suatu masalah dalam realita kehidupan (Muna, 2016). Lebih lanjut dikemukakan Muna bahwa melalui kegiatan praktikum, peserta didik dapat membuktikan konsep atau teori yang sudah ada dan dapat mengalami proses atau percobaan itu sendiri serta mengambil kesimpulan sehingga dapat menunjang pemahaman peserta didik terhadap materi pelajaran (Muna, 2016). Namun sangat disayangkan bahwa pada kenyataannya, pembelajaran sains di sekolah-sekolah telah mengalami perubahan. Kemungkinan juga dapat terjadi bahwa pembelajaran sains akan dapat kehilangan makna sehingga menjadi sebuah pembelajaran sastra. Pada kenyataannya, kegiatan pembelajaran sains di sekolah seringkali tidak sejalan dengan hakikat sains yang sebenarnya (Hendrawati, 2012).

Berdasarkan hasil pengamatan peneliti di sekolah, dapatlah dikatakan bahwa guru-guru yang mengampu mata pelajaran sains, hanya $20 \%$ yang melaksanakan praktikum di dalam proses kegiatan belajar-mengajarnya; sedangkan $80 \%$ sisanya menyampaikan materi pembelajaran tanpa aktivitas praktikum di laboratorium. Keadaan yang demikian ini dapat terjadi karena beberapa faktor, seperti misalnya: (1) belum tersedianya sarana dan prasarana laboratorium IPA di sekolah; (2) kegiatan praktikum sulit dilakukan dan berbahaya; (3) tidak adanya pengelola laboratorium khusus; (4) banyak waktu terbuang; dan (5) menimbulkan kerepotan dan kegaduhan serta siswa kurang fokus pada kegiatan pembelajaran.

Minimnya keterampilan guru untuk membimbing peserta didik melaksanakan kegiatan praktikum dan kurangnya kesadaran guru akan pentingnya pelaksanaan praktikum dalam pembelajaran sains juga menjadi faktor pendukung tidak terlaksananya praktikum dalam pembelajaran di sekolah. Sehubungan dengan hal ini, Setiadi dan Muflika (2012) mengemukakan bahwa tidak semua sekolah pada pembelajaran kimia melakukan praktikum. Faktor penyebab sekolah yang tidak melakukan praktikum adalah dikarenakan kurangnya kesadaran guru mengenai pentingnya melakukan praktikum, dan kurang tersedianya alat dan bahan yang dibutuhkan untuk praktikum.

Berdasarkan uraian yang telah dikemukakan, peneliti tertarik untuk melakukan penelitian/kajian tentang peluang dan kemungkinan tantangan pemanfaatan Laboratorium Maya dalam melaksanakan kegiatan praktikum IPA. Peluang dan tantangan inilah yang menjadi fokus pembahasan di dalam penelitian/kajian ini. Pemanfaatan Laboratorium Maya dilakukan hanya dengan memanfaatkan aplikasi yang 
tersedia di portal Rumah Belajar. Tujuan dari kajian ini adalah untuk mengetahui peluang dan tantangan pemanfaatan Laboratorium Maya dalam proses kegiatan pembelajaran.

Keprihatinan atas kondisi pembelajaran sains dewasa ini telah banyak dirasakan oleh berbagai pihak. Namun yang lebih memprihatinkan lagi adalah pada pemberdayaan pembelajaran praktikum di bidang sains yang menuntut keterampilan. Kebutuhan akan penggunaan Laboratorium Maya telah diantisipasi oleh Pusat Teknologi Informasi dan Komunikasi Pendidikan dan Kebudayaan (pada tahun 2011) dengan mengembangkan portal Rumah Belajar yang di dalamnya terdapat fitur Iayanan Laboratorium Maya (Warsita, 2019).

Setelah portal Rumah Belajar dirancang dan dikembangkan, dilakukan sosialisasi kepada masyarakat luas, terutama masyarakat pendidikan sejak tahun 2011. Sebagai sebuah portal pembelajaran yang berbasis web, portal ini berisikan berbagai layanan pembelajaran, seperti: Kelas Maya, Laboratorium Maya, Sumber Belajar, dan Peta Budaya. Portal Rumah Belajar ini merupakan portal pembelajaran resmi milik Kementerian Pendidikan dan Kebudayaan yang dapat diakses peserta didik, guru, orang tua, dan masyarakat luas dengan alamat URL http:// belajar.kemdikbud.go.id.

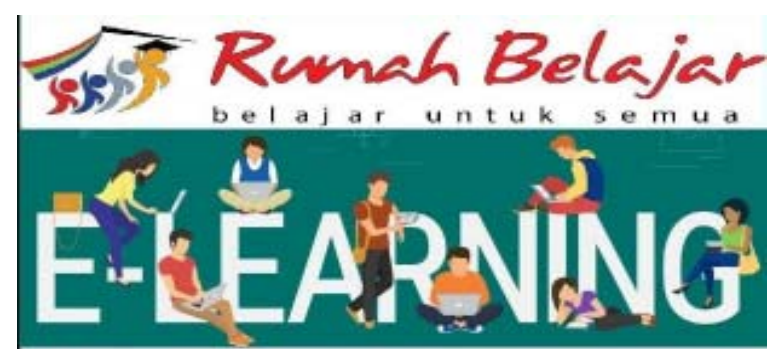

Mari belajar dan bergabung dengan pengguna Lainnya di Rumah Belajar

Apa itu Portal Rumah Belajar?

RUMAH BELAJAR merupakan hasil pengembangan portal sebelumnya yang diluncurkan pada 15 Juli 2011, berisi konten bahan belajar yang dapat dimanfaatkan oleh pendidik dan peserta didik Pendidikan Anak Usia Dini (PAUD), Sekolah Dasar (SD) hingga Sekolah Menengah Atas/Kejuruan (SMA/SMK) sebagai sumber media pembelajaran

\section{Mari belajar dan bergabung dengan pengguna lainnya di Rumah Belajar}
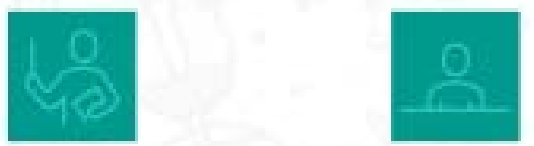

266.045

Guru

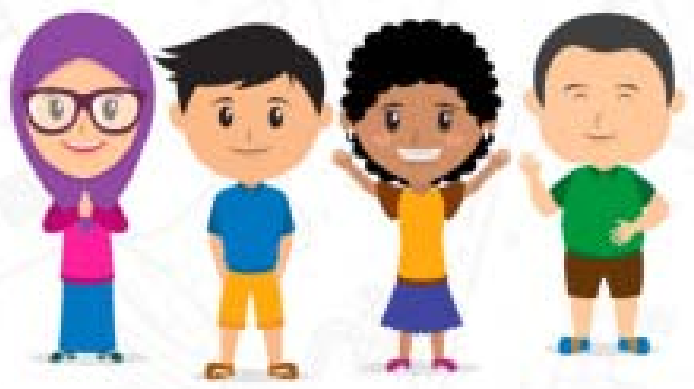

Gambar: 1. Tampilan Awal Rumah Belajar

Portal Rumah Belajar terdiri dari dua bagian, yaitu bagian fitur utama dan fitur penunjang. Fitur utama terbagi menjadi delapan fitur yang dapat dimanfaatkan, yaitu: (1) Sumber Belajar; (2) Laboratorium Maya; (3) Bank Soal; (4) Kelas Digital; (5) Buku Sekolah Elektronik (BSE); (6) Peta Budaya; (7) Wahana Jelajah Angkasa; dan (8) Pengembangan Keprofesian Berkelanjutan (PKB)/Diklat Online. Tampaklah ada sebuah fitur yang disediakan di portal Rumah Belajar, yang diberi nama Laboratorium Maya (virtual laboratory).

Selain terdiri dari delapan fitur utama di dalam portal Rumah Belajar, terdapat pula fitur tambahan yang terdiri dari Karya Komunitas, Karya Guru, dan Karya Bahasa dan Sastra. 


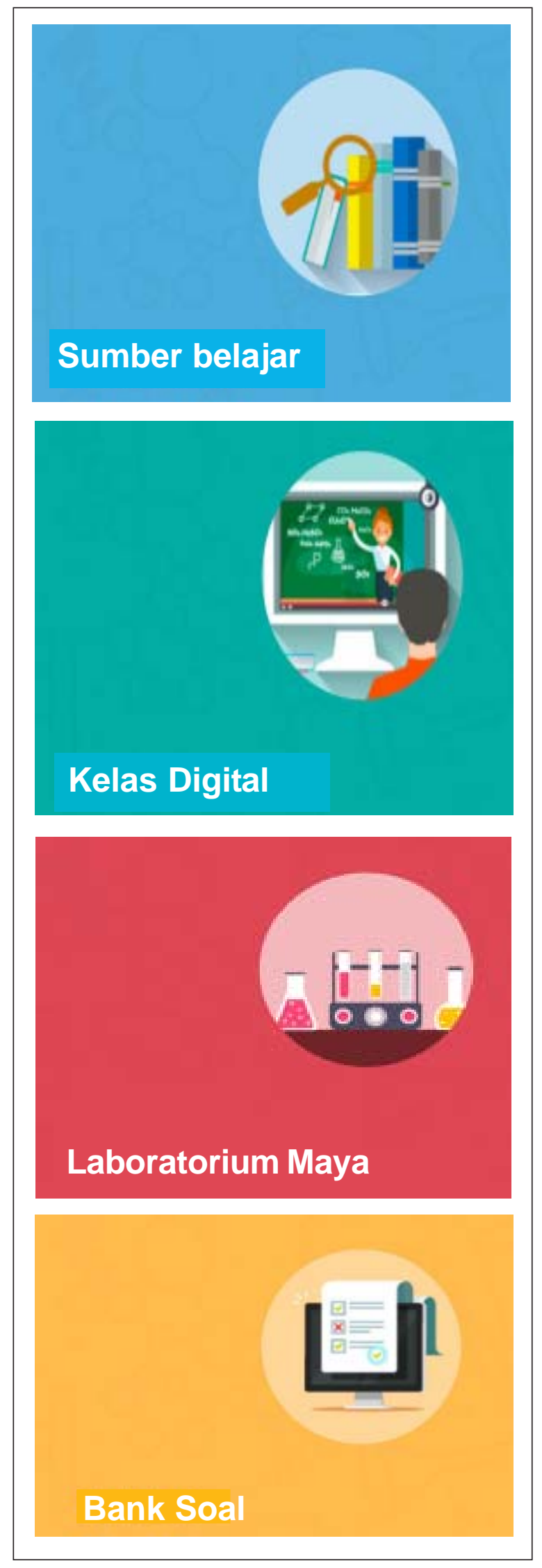

Gambar: 2. Tampilan Fitur Utama

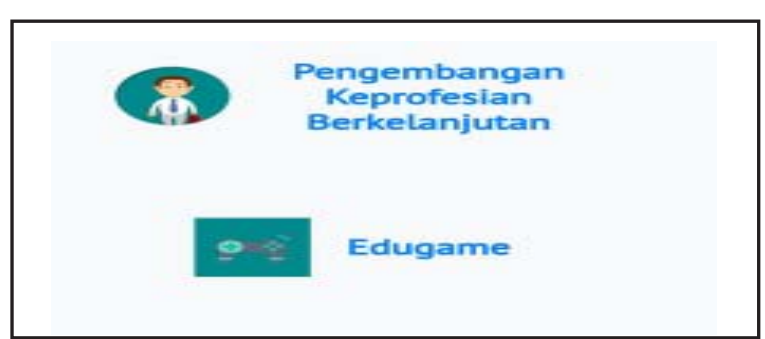

Gambar 3. Tampilan fitur lainnya

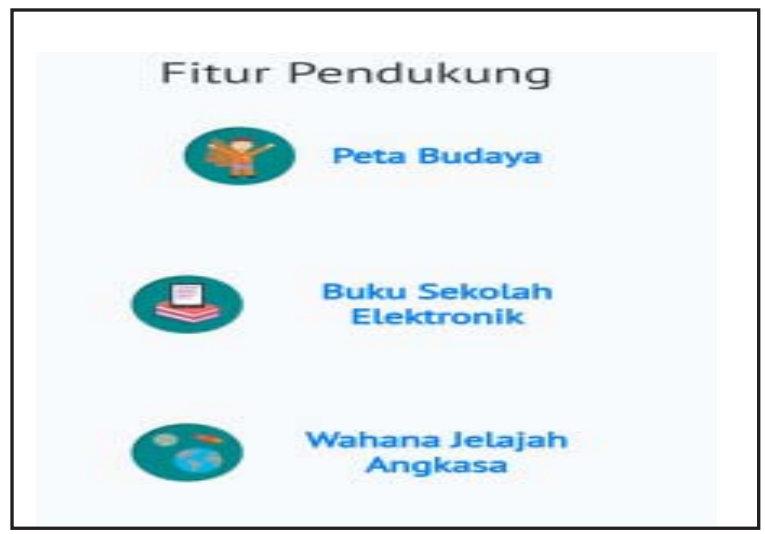

Gambar 4. Tampilan fitur Pendukung

Untuk dapat memanfaatkan berbagai fitur yang tersedia pada portal Rumah Belajar secara lengkap dan optimal, pengguna harus memiliki jaringan internet dan beberapa perangkat teknologi lainnya, seperti komputer beserta perangkat lunak (software) pendukung. Laboratorium Maya terdapat pada Portal Rumah Belajar di kelompok fitur utama, dengan tampilan yang disajikan pada Gambar 5 berikut ini.

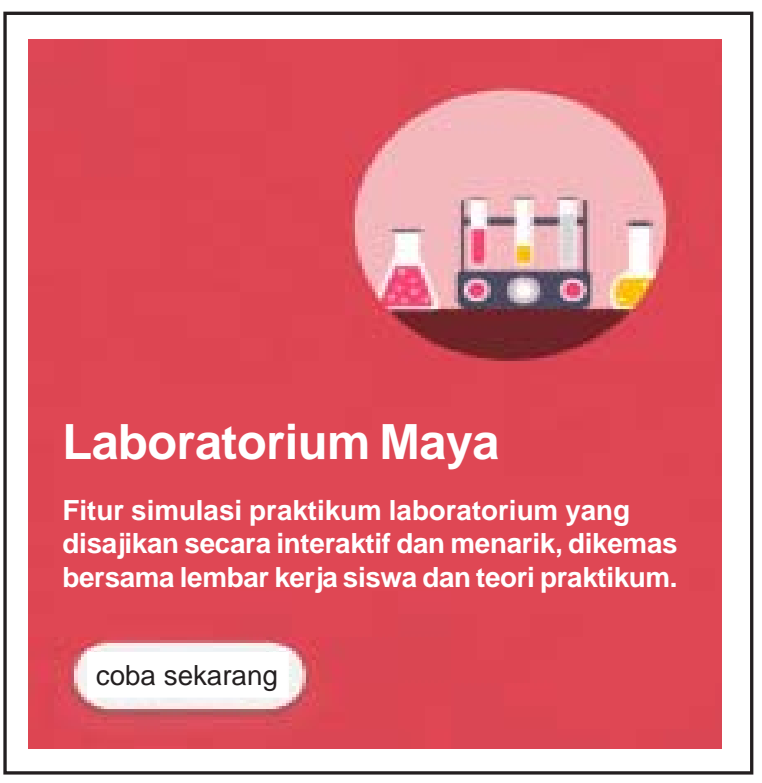

Gambar: 5. Tampilan laboratorium maya 


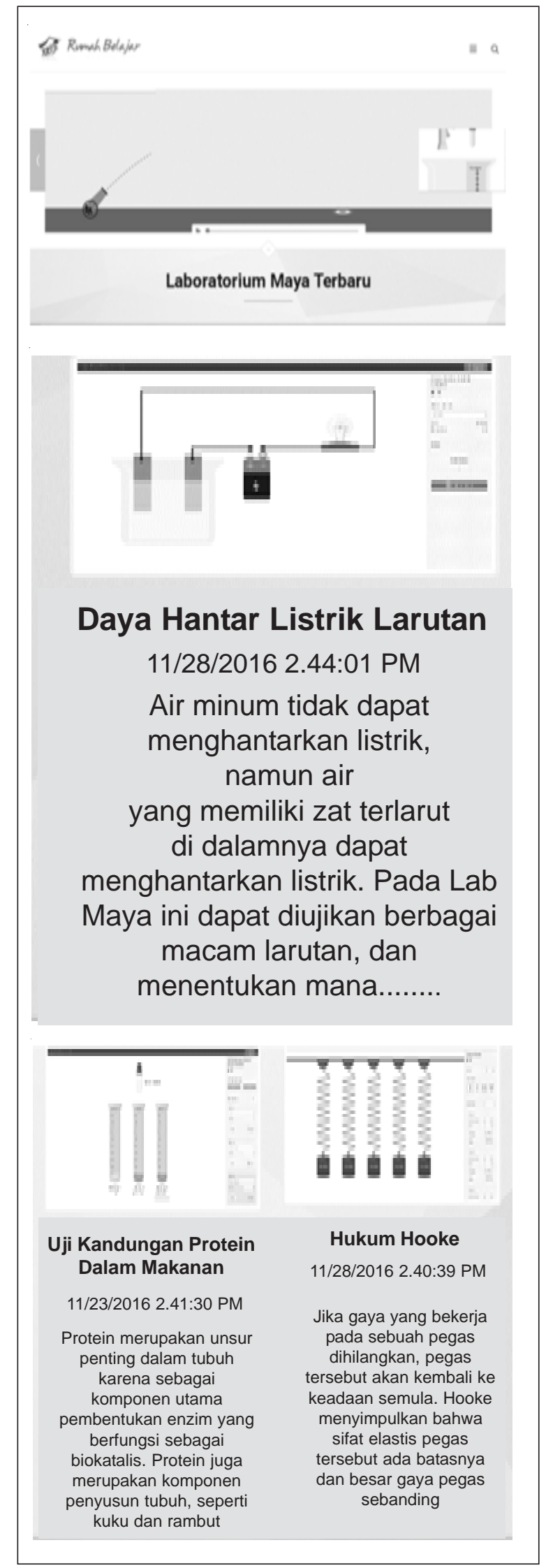

Gambar 6. Tampilan Beranda Laboratorium Maya di Rumah Belajar
Laboratorium Maya ini dimaksudkan untuk melengkapi sumber belajar peserta didik khususnya dalam hal melakukan praktikum dengan menyediakan Laboratorium Maya yang dapat diakses kapan pun dan di mana pun (http://vlab.belajar.kemdikbud,go.id). Sepanjang tersedia perangkat komputer dan koneksi internet, Laboratorium Maya ini dapat dimanfaatkan dan pada praktiknya Laboratorium Maya telah banyak berperan dengan baik dalam mendukung pembelajaran.

Keberadaan Laboratorium Maya diperuntukkan untuk memudahkan siapa pun untuk belajar kapan saja dan di mana saja, dengan biaya yang sangat terjangkau atau bahkan tanpa biaya (gratis) (Nirwana, 2011). Terlebih lagi, dari beberapa hasil penelitian, dapat disimpulkan bahwa Laboratorium Maya ini sangat baik diterapkan pada proses pembelajaran di sekolah. Hal ini sesuai dengan hasil penelitian Hendra Jaya (2012) yang mengemukakan bahwa proses praktikum melalui simulasi di laboratorium virtual dengan menggunakan karakter dan penampakan lingkungan virtual (mirip peralatan nyata) dapat memfasilitasi peserta didik untuk terlibat dan berpikir secara aktif menggantikan peralatan yang sebenarnya.

Kemudian, hasil penelitian Ponimin (2010) mengungkapkan bahwa memadukan laboratorium riil dan virtual disertai penugasan peserta didik berbasis multimedia pada pembelajaran getaran dan gelombang dapat meningkatkan kualitas peserta didik, baik materi teori maupun eksperimen. Sekalipun kemajuan TIK telah mendorong terciptanya laboratorium virtual, namun masih sedikit jumlah sekolah di Indonesia yang telah memiliki dan menggunakan Laboratorium Maya. Dari hasil penelitiannya, Nirwana (2011) berharap bahwa di masa mendatang, laboratorium virtual dan e-references di Indonesia yang tersedia secara gratis akan semakin banyak dikembangkan dan dimanfaatkan. Riset-riset juga akan semakin maju, proses pendidikan juga semakin menyenangkan, dan biaya pendidikan pun akan semakin terjangkau masyarakat. 


\section{METODA}

Metoda yang digunakan untuk membahas masalah yang terdapat di dalam artikel ini adalah studi literatur. Pengkajian dilakukan mengenai konsep dan teori yang digunakan berdasarkan literatur yang tersedia, terutama dari artikel-artikel yang dipublikasikan dalam berbagai jurnal ilmiah.

Sumber data didapat dari sumber primer dan sumber sekunder, baik berupa laporan/ kesimpulan seminar, catatan/rekaman diskusi ilmiah, tulisan-tulisan resmi terbitan pemerintah dan lembaga-lembaga lain, maupun dalam bentuk buku/manual digital seperti bentuk piringan optik, komputer atau data komputer. Pengumpulan data/informasi melalui studi literasi berlangsung selama 2 bulan (Juli-Agustus 2019).

Untuk memperoleh hasil yang benar dan tepat dalam menganalisis data, penulis menggunakan teknik analisis isi (Content Analysis). Data yang diperoleh dikompilasi, dianalisis, dan disimpulkan, kemudian disajikan secara deskriptif sehingga mendapatkan kesimpulan mengenai peluang dan tantangan pemanfaatan Laboratorium Maya yang terdapat pada portal Rumah Belajar.

\section{HASIL DAN PEMBAHASAN}

Pembelajaran sains meliputi beberapa pembelajaran keterampilan motorik yang harus dicapai peserta didik, yaitu yang berupa: keterampilan mengamati (observing), melakukan klasifikasi (classifying), berkomunikasi (communicating), mengukur (measuring); menyimpulkan (inferring), meramal memprediksi (predicting), menginterpretasi/ menerjemahkan/ menafsirkan (interpretation), merumuskan hipotesis, merencanakan penelitian, menerapkan konsep atau prinsip, serta mengajukan pertanyaan yang harus didapatkan siswa saat melakukan inquiry ilmiah.

Pada pembelajaran sains, terdapat suatu metode yang dikenal dengan metode ilmiah. Hal ini menunjukkan bahwa di dalam pembelajarannya, diperlukan sebuah laboratorium sebagai tempat untuk mentransfer ilmu pengetahuan dan keterampilan melalui suatu kegiatan yang disebut praktikum. Lebih jauh, Rahmawati menyatakan bahwa Laboratorium Maya dapat berubah fungsi menjadi kelas, dalam artian bahwa ketersediaan laboratorium dalam pembelajaran merupakan salah satu sarana yang akan dipakai untuk melakukan kegiatan belajar-mengajar (Rahmawati, 2010).

Ketersediaan fasilitas dan sarana penunjang pembelajaran merupakan satu indikator kualitas pendidikan. Dalam kaitan ini, Rizki (2013) mengemukakan bahwa kualitas sebuah lembaga pendidikan diukur berdasarkan ketersediaan fasilitas dan sarana pembelajaran yang dimilikinya. Namun menurut Hafiar, et al., (2017), ketersediaan fasilitas dan sarana pembelajaran saja belumlah cukup. Masih diperlukan adanya pengawasan dan perawatan agar kondisi fasilitas tetap terjaga dengan layak. Ini berarti bahwa pembelajaran Sains sangat membutuhkan adanya laboratorium, fasilitas, pengawasan dan perawatan untuk melakukan praktikum sehingga pendidikan itu berkualitas.

Pada kenyataannya, kondisi sekolahsekolah di Indonesia masih banyak yang belum bisa melaksanakan kegiatan pembelajaran di laboratorium. Faktor penyebab belum dimungkinkannya semua sekolah melakukan kegiatan praktikum adalah dikarenakan masih adanya sekolahsekolah yang belum memiliki gedung laboratorium beserta berbagai perangkat pendukungnya.

Kendala berikutnya dilihat dari segi sekolah dan guru (di sekolah) adalah yang berupa kemampuan guru yang tidak atau belum memungkinkan mereka untuk melaksanakan kegiatan praktikum. Kemampuan guru belum maksimal untuk melaksanakan kegiatan pembelajaran secara baik terutama mengenai kegiatan praktikum. Kondisi yang demikian ini tampak mulai dari menggunakan alat laboratorium, memfasilitasi ketersediaan semua materi praktikum pembelajaran sains, sampai dengan ketersediaan dan cara menanggulangi dengan keselamatan kerja dalam praktikum di laboratorium. 
Untuk mengatasinya, guru dapat menggunakan Laboratorium Maya. Laboratorium Maya adalah suatu alat pembelajaran berupa software yang berisi peristiwa atau jalannya percobaan dalam bentuk animasi. Program ini sangat mudah diperoleh dan dioperasikan, baik oleh guru maupun siswa, karena hanya menggunakan komputer dan koneksi internet.

Revolusi Industri 4.0 merupakan sebuah tren yang melanda semua negara di dunia, termasuk Indonesia. Oleh karena itu, Indonesia harus siap mengikuti dan melaksanakan Revolusi Industri 4.0. Revolusi Industri 4.0 ini menyasar hampir seluruh bidang kehidupan dan salah satu bidang yang mau tak mau, siap atau tidak siap, adalah bidang pendidikan. Bagaimana kesiapan Indonesia di bidang pendidikan untuk melaksanakan dan terlibat aktif dalam pendidikan 4.0. seperti negara-negara lain di dunia?

Indonesia siap karena telah memiliki portal Rumah Belajar, yaitu suatu portal yang dirancang dan dikembangkan oleh Kementerian Pendidikan dan Kebudayaan melalui Pustekkom (yang sekarang bernama Pusdatin), dengan laman: http:// belajar.kemdikbud.go.id (Warsita, 2019). Kehadiran portal Rumah Belajar di dunia maya (internet) menambah khasanah sumber belajar bagi dunia pendidikan di Indonesia. Portal Rumah Belajar memfasilitasi terjadinya pembelajaran berbasis teknologi atau pembelajaran online (Warsita, 2019). Pembelajaran online bisa terlaksana akibat adanya inovasi dan perkembangan yang pesat pada dunia TIK.

Penerapan TIK telah melahirkan model baru dalam pembelajaran (Kusnohadi, 2014). Salah satu wujudnya yang bisa dilihat adalah keberadaan Laboratorium Maya pada fitur portal Rumah Belajar. Laboratorium Maya tercipta berkat adanya inovasi yang terusmenerus pada dunia TIK dan multimedia. Laboratorium Maya merupakan serangkaian alat-alat laboratorium yang berbentuk perangkat lunak (software) komputer berbasis multimedia interaktif yang dioperasikan dengan komputer dan dapat mensimulasikan kegiatan di laboratorium seakan-akan pengguna berada pada laboratorium sebenarnya.

Laboratorium Maya dibuat dengan berbagai program misalnya makromedia flash. Siswa dapat melakukan percobaan sendiri dengan melihat tayangan pada layar komputer. Dengan menggunakan software ini, siswa dapat mengulang-ulang suatu percobaan dengan menggunakan komputer, mengadakan perubahan data yang dikehendaki atau sekedar melihat jalannya suatu percobaan, peristiwa, perubahan besaran, dan lain-lain tergantung dari software yang sudah tersedia.

Dengan menggunakan Laboratorium Maya, peserta didik seolah-olah belajar dengan perangkat laboratorium nyata, walaupun hanya semu karena hanya dengan animasi. Menurut Nirwana (Nirwana, 2011), keberadaan Laboratorium Maya tentu saja semakin mempermudah proses pembelajaran dan juga proses riset yang dilakukan, baik pada kegiatan pembelajaran maupun kegiatan penelitian.

Pemanfaatan Laboratorium Maya dalam proses kegiatan pembelajaran pada pembelajaran sains memiliki peluang yang sangat menjanjikan karena berdasarkan data tahun 2012, penetrasi penggunaan internet di wilayah urban Indonesia mencapai 24,23\% (Subroto, 2015). Jumlah yang sangat luar biasa jika dibandingkan dengan jumlah penduduk Indonesia yang mencapai 260 juta jiwa (BPS, 2012). Data dari lembaga riset pasar e-Marketer menginformasikan bahwa populasi netter Tanah Air mencapai 83,7 juta orang pada 2014. Ini membuktikan bahwa penduduk Indonesia sudah melek internet dan telah mengakses serta menggunakannya dalam kehidupan sehari-hari.

Selanjutnya, masalah yang menarik untuk diperbincangkan adalah bagaimana guru membudayakan, meluruskan, dan menghadirkan pemanfaatan TIK, tidak hanya di dalam sekolah tetapi juga di dalam kegiatan pembelajaran yang menjadi tugas dan tanggung jawab profesionalnya.

Pertama, kegiatan yang dapat dilakukan guru adalah memanfaatkan keberadaan portal Rumah Belajar dan terutama Laboratorium Maya kepada masyarakat pendidikan di 
lingkungan sekolah. Di dalam portal Rumah Belajar, tersedia berbagai ragam konten pembelajaran yang dapat diakses melalui internet. Konten-konten ini bebas dan gratis dimanfaatkan, baik untuk kepentingan peserta didik, guru maupun orang tua. Berbagai konten yang tersedia ini bisa menunjang kegiatan-kegiatan pelaksanaan pembelajaran yang tidak bisa dihadirkan dan dilakukan di dalam kondisi nyata. Konten-konten yang tersedia di portal Rumah Belajar dapat menjadi solusi terhadap kendala-kendala tertentu, baik berupa kurangnya saranaprasarana maupun kondisi-kondisi lapangan lainnya.

Laboratorium Maya, sebagai salah satu fitur yang tersedia di portal Rumah Belajar, dapat diperkenalkan dan dihadirkan dengan peluang besar untuk dimanfaatkan pada kegiatan pembelajaran, terutama pada pelaksanaan kegiatan-kegiatan praktikum di laboratorium. Tidak terlaksananya kegiatan praktikum pada pembelajaran siswa karena laboratorium nyata yang ada di sekolah belum dilengkapi dengan fasilitas laboratorium, baik fasilitas yang berupa bangunan, peralatan laboratorium, maupun spesimen IPA.

Demikian juga dengan keterbatasan tenaga pengelola laboratorium yang terdiri dari kepala sekolah, wakil kepala, kepala laboratorium, laboran, asisten laboran, yang kesemuanya harus memiliki pemahaman dan keterampilan kerja di laboratorium, yang saling berkerjasama sesuai dengan tugas dan tanggung jawab yang telah ditetapkan dan sunguh-sunguh mengikuti peraturan.

Laboratorium Maya merupakan solusi bagi sekolah yang terkendala untuk melaksanakan kegiatan praktikum di kegiatan pembelajaran. Portal Rumah Belajar merupakan salah satu solusi dan peluang yang baik untuk dimanfaatkan di dalam kegiatan belajarmengajar karena Laboratorium Maya ini dimaksudkan untuk melengkapi sumber belajar peserta didik khususnya dalam hal melakukan praktikum (Pustekkom, 2017). Kondisi tersebut diperkuat lagi dengan pendapat yang dikemukakan Jasmadi (2018), yaitu bahwa pada proses pembelajaran Fisika, praktikum merupakan salah satu metode belajar yang memberikan suatu pengalaman langsung kepada peserta didik (to experience) di laboratorium, sampai saat ini, belum semua sekolah mempunyai alatalat laboratorium yang lengkap, biaya pengadaan bahan-bahan praktikum dan resiko keamanan saat praktikum masih menjadi kendala. Salah satu solusi untuk tetap memberikan kemampuan pembelajaran dalam keterbatasan ini adalah dengan melaksanakan praktikum secara virtual. Hal ini sejalan juga dengan pendapat Ponimin (2010) yang mengatakan bahwa laboratorium virtual merupakan pilihan yang tepat untuk mempermudah pelaksanaan praktikum Sistem Operasi.

Berbagai penelitian yang telah dilakukan, didapat beberapa manfaat dan peluang dari penggunaan Laboratorium Maya. Menurut Ferreira dkk. (2010), manfaat penggunaan laboratorium virtual secara online adalah: (1) mengurangi keterbatasan waktu; (2) mengurangi hambatan geografis; (3) lebih ekonomis; (4) meningkatkan kualitas eksperimen; (5) meningkatkan efektivitas pembelajaran; dan (6) meningkatkan keamanan dan keselamatan.

Menurut peneliti dari Labshare, kelebihan dari laboratorium virtual yang dirujuk Nirwana, yaitu: (1) meningkatkan jumlah pengakses laboratorium maya; (2) menurunkan biaya pengelolaan dan pemeliharaan laboratorium sebesar 50\%; dan (3) meningkatkan pembelajaran untuk mensupport pembelajaran yang lebih baik.

Secara finansial, menurut Nirwana (2011), penggunaan laboratorium virtual dan simulasi kompleks relatif sangat terjangkau. Dengan adanya Laboratorium Maya ini, peserta didik dimungkinkan untuk melakukan praktikum melalui Laboratorium Maya. Peserta didik dalam melaksanakan kegiatan praktikum melalui Laboratorium Maya, seolah-olah mereka menghadapi fenomena atau perangkat peralatan laboratorium nyata. Kondisi yang demikian ini menunjukkan dan menjelaskan tentang besarnya peluang untuk memanfaatkan Laboratorium Maya terutama di dunia pendidikan. Melalui pemakaian Laboratorium Maya, dapat dilaksanakan 
kegiatan pembelajaran sains yang berupa praktikum walaupun di sekolah tersebut tidak tersedia sarana dan prasarana pendukungnya.

Kemudian, menurut Setiadi dan Muflika (2012), laboratorium virtual memiliki beberapa kelebihan, yaitu: (1) dapat dimanfaatkan di mana saja dan kapan saja; (2) tidak memerlukan alat dan bahan kimia; dan (3) dapat mengamati aspek molekuler, seperti pergerakan partikel, antarpartikel, interaksi antarpartikel, perubahan struktur materi karena pengaruh lingkungan atau pembacaan suatu data dalam bentuk angka dan perubahannya terjadi secara langsung.

Hasil penelitian tentang penggunaan Laboratorium Maya dalam pembelajaran menunjukkan adanya peluang yang sangat menjanjikan. Hasil pemanfaatan Laboratorium Maya menunjukkan hasil positif dan sangat baik, terutama ketika digandeng untuk meningkatkan pemahaman, hasil pengetahuan, dan sikap peserta didik bila dibandingkan dengan penggunaan laboratorium nyata atau konvensional. Kondisi yang demikian ini terbukti dari hasil kajian beberapa peneliti. Di antaranya adalah seperti yang telah disampaikan Nur Hikmah (2018) pada penelitiannya yang berjudul "Penerapan Laboratorium Virtual untuk Meningkatkan Pemahaman Konsep Siswa", didapat kesimpulan bahwa adanya pengaruh penerapan simulasi laboratorium virtual terhadap pemahaman konsep peserta didik pada materi laju reaksi. Melalui penilaian akhir didapatkan nilai rata-rata pada kelas eksperimen yang lebih unggul dari pada nilai rata-rata kelas kontrol. Hal ini didukung juga dengan penelitian yang dilakukan Hermansyah et al. (2015) bahwa belajar dengan menggunakan laboratorium virtual dapat berpengaruh terhadap peningkatan penguasaan konsep belajar.

Kemudian, Sumargo dan Yuanita (2014) juga mengatakan hal yang sama bahwa pembelajaran dengan menggunakan laboratorium virtual PhET berbasis simulasi ini dapat meningkatkan pemahaman konsep peserta didik sehingga terjadi peningkatan nilai hasil belajar mereka.
Menurut Nurrokhmah dan Sunarto (2013), belajar dengan menggunakan laboratorium virtual membuat kegiatan pembelajaran menjadi lebih menarik. Ketertarikkan peserta didik dalam belajar dengan menggunakan laboratorium virtual ini dapat menambah semangat belajar mereka dan membuat mereka lebih aktif sehingga dapat membantu memahami konsep yang diajarkan.

Berdasarkan hasil penelitiannya, Jagodzinski dan Wolski (2014) menyatakan bahwa pembelajaran menggunakan laboratorium virtual berdampak positif, baik pada peningkatan efisiensi pengajaran maupun peningkatan kemampuan mengingat (retensi) peserta didik terhadap informasi (konsep) materi.

Indikator memahami (C2) pada kelompok kontrol dengan kategori baik dan kelompok eksperimen dengan kategori sangat baik. Hal ini disebabkan karena peserta didik dihadapkan dengan simulasi berupa tiruan-tiruan seperti keadaan yang sebenarnya dari suatu konsep. Peserta didik dengan mudah dapat menafsirkan dan menjelaskan konsep tersebut. Hal ini sejalan dengan teori yang menyatakan bahwa media simulasi dalam proses pembelajaran membuat peserta didik termotivasi dalam belajar serta memudahkan peserta didik memahami konsep dasar (Larasati dan Sukisno, 2014).

Jaya Hendra (2012) mengatakan bahwa laboratorium virtual bersifat interaktif, dinamis, animatif, dan berlingkungan virtual. Dengan demikian, pembelajaran dengan menggunakan Laboratorium Maya tidak membosankan tetapi mendukung kegiatan praktikum dan sekaligus juga mendukung keinginan pengguna. Di dalam penelitiannya, Jaya Hendra menyatakan bahwa Laboratorium Maya dapat memfasilitasi karakter yang ingin dikembangkan, seperti karakter yang dapat dipercaya, saling menghargai, tanggung-jawab individu, tanggung jawab sosial, adil, dan peduli.

Dengan semakin majunya teknologi yang dibawa ke dalam kelas dan khususnya untuk kepentingan kegiatan praktikum, tantangan awal dari Laboratorium Maya adalah apakah sekolah tersebut sudah memiliki sarana dan fasilitas internet yang baik (memadai) dalam memfasilitasi kegiatan pembelajaran. 
Demikian juga dengan kesiapan sumber daya yang ada di lingkungan lembaga pendidikan tersebut untuk mengoperasikan dan menerapkan serta sekaligus menjadi fasilitator dalam pelaksanaan kegiatan praktikum melalui Laboratorium Maya. Hal ini sejalan dengan pendapat Sudirman Siahaan (2018) yang menyatakan bahwa guru harus terlebih dahulu dituntut untuk membelajarkan TIK bagi dirinya sendiri.

Di samping itu, guru juga hendaknya memiliki kemampuan untuk mengembangkan atau setidak-tidaknya mampu mencari berbagai konten pembelajaran yang dibutuhkan peserta didik guna mencapai kompetensi yang diinginkan. Tantangan yang selanjutnya adalah seperti yang disinyalir oleh UNESCO (2013) yaitu ketersediaan akan sumber daya tenaga listrik, ketersediaan jaringan telekomunikasi, belum memadainya ketersediaan tenaga yang mampu mengelola peralatan, masih relatif tingginya biaya akses internet, dan masih kurangnya sumbersumber belajar digital berbahasa Indonesia yang tersedia.

Tantangan berikutnya yang juga perlu mendapat perhatian adalah kelemahan dari Laboratorium Maya itu sendiri. Dalam kaitan ini, Nirwana (2011) berpendapat yang didasarkan atas hasil penelitiannya bahwa kelemahan dari Laboratorium Maya adalah berupa: kurangnya pengalaman peserta didik untuk menyelesaikan masalah di samping keterampilan merangkai alat yang didapat atau tersedia di sekolah.

Kemudian, Setiadi dan Muflika (2012) juga mendasarkan pada hasil penelitian mereka yang mengungkapkan bahwa Laboratorium Maya di samping memiliki kelebihan, juga memiliki kekurangan, yaitu akan hilangnya kemampuan motorik siswa. Ketika kegiatan praktikum dilaksanakan berbasis Laboratorium Maya, pada proses kegiatan pelaksanaannya, siswa tidak melakukan kegiatan praktikum secara nyata, seperti menuang larutan, mengukur larutan dengan menggunakan gelas ukur, dan merangkai alat. Beberapa hasil penelitian lain yang relevan yang telah dilakukan mengatakan bahwa pemakaian Laboratorium Maya hanya unggul pada hasil tes pemahaman konsep (C2), kemampuan menerapkan (C3), dan untuk kemampuan menganalisis (C4) hasil yang didapat rendah. Hal ini terjadi dikarenakan pada prinsipnya Laboratorium Maya memang hanya ditujukan sebagai bentuk tiruan dari sebuah laboratorium riil yang digunakan dalam aktivitas pembelajaran. Penelitian secara ilmiah yang digunakan untuk menekankan sebuah konsep atau mendalami konsep-konsep tertentu.

Laboratorium virtual diperlukan untuk memperkuat pemahaman konsep dalam proses pembelajaran. Laboratorium virtual bukanlah pengganti tetapi bagian dari laboratorium riil yang digunakan untuk melengkapi dan memperbaiki kelemahankelemahan yang ada (Pustekkom, 2017). Selain itu, dalam simulasi laboratorium virtual, kurang mendukung dalam hal pengaplikasian rumus atau mencari keputusan dengan jalan perhitungan.

Sama halnya seperti penelitian yang dilakukan Ekasari (2016) bahwa hasil pada kategori C3 mendapatkan hasilnya yang sama dengan $\mathrm{C} 4$, namun masih lebih unggul pada persentase pencapaian pada C2. Penyebabnya adalah dikarenakan kurangnya diberikan soal-soal latihan tingkat sedang dan tinggi.

\section{SIMPULAN DAN SARAN}

\section{Simpulan}

Berdasarkan hasil analisis dan pembahasan di atas, dapat disimpulkan bahwa laboratorium virtual sangat bermanfaat dan diperlukan untuk memperkuat pemahaman konsep dalam proses pembelajaran. Pemanfaatan Laboratorium Maya berpeluang sangat besar untuk dipakai dalam proses kegiatan pembelajaran di sekolah-sekolah. Hal ini terlihat dari data bahwa pemakaian internet oleh masyarakat Indonesia yang sangat tinggi.

Laboratorium Maya mampu melaksanakan kegiatan pembelajaran praktikum pada mata pelajaran sains walaupun fasilitas dan sarana prasarana fisik tidak atau kurang mendukung pada suatu sekolah. Laboratorium Maya juga merupakan kegiatan praktikum yang menarik, mudah 
dilaksanakan, mampu mengatasi pelaksanaan praktikum yang mahal, sulit, dan berbahaya.

\section{Saran}

Berdasarkan simpulan yang telah di kemukakan, penulis memberikan saransaran untuk dapat dipertimbangkan. Diperlukan kerjasama berbagai pihak agar sekolah-sekolah mempunyai sumber daya tenaga listrik, perangkat TIK, koneksi internet, dan tenaga yang melek TIK. Di samping itu, diperlukan pelatihan dan pembinaan tenaga pendidik dan kependidikan secara teratur di bidang pemanfaatan media berbasis TIK khususnya pemanfaatan Laboratorium Maya.

Tantangan kedepannya bagi Laboratorium Maya adalah harus mampu menyediakan semua materi kegiatan praktikum pada pembelajaran sains, menghadirkan kegiatan praktikum yang memang sulit untuk dilaksanakan pada laboratorium konvesional/ laboratorium rill.

Tantangan berikutnya adalah kemampuan untuk membuat dan menyediakan contohcontoh bahan praktikum yang ketika pelaksanaannya di laboratorium konvensional akan memakan biaya yang sangat tinggi atau mahal, serta mampu menyediakan dan menyajikan kegiatan-kegiatan praktikum yang sulit dilaksanakan, dan sangat berbahaya, jika dilakukan praktikum pada laboratorium konvensional.

Selanjutnya, tantangan yang juga akan dihadapi adalah kemampuan membuat kegiatan praktikum yang interaktif sehingga siswa memiliki keterampilan merangkai alat dan menyelesaikan masalah. Tantangan berikutnya adalah kemampuan mengenal dan menemukan bentuk alat dan bahan dari kegiatan praktikum, dan kemampuan mendukung pengaplikasian rumus atau mencari keputusan dengan jalan perhitungan sehingga siswa memperoleh keterampilan motorik, tidak hanya mencapai kemampuan konsep-konsep saja.

\section{PUSTAKA ACUAN}

\section{Buku}

UNESCO Asia-Pacific Regional Bureau for Education APEID/ICT Education. (2013). ICT in Education, Policy, Infrastructure, and ODA Status in Selected ASEAN Countries. Bangkok: UNESCO Asia-Pacifik Regional 429 Bereau for Education APEID/ICT Education. Sumber: http:www.unescobkk.org/fileadmin/ u s e r_ U p l o a d / i c t / e b o o k s / ICT_in_Education_policies_Infrastructure_andODA.pdf (Diakses tanggal 28 Agustus 2019).

\section{Jurnal/Prosiding/Disertasi/Tesis/Skripsi}

Agustina, Maya. (2018). Peranan Laboratorium IImu Pengetahuan Alam (IPA) dalam Pembelajaran IPA Madrasah Ibtidaiyah (MI)/ Sekolah Dasar (SD). At-Ta'dib: Jurnal IImiah Pendidikan Agama Islam, Volume 10, No. 1, Juni 2018.

Hafiar, H. dan Jimi N. M. (2017). Tantangan Optimalisasi Peran Laboratorium TV di Peruguruan Tinggi Profetik. Jurnal Komunikasi. Vol. 10 No. 02, Oktober 2017.

Hermansyah, et al. (2015). Pengaruh Pengunaan Laboratorium Virtual Terhadap Penugasan Konsep dan Kemampuan Berpikir Kreatif Siswa Pada Materi Getaran dan Gelombang. Jurnal Pendidikan Fisika dan Teknologi. Vol.1 No. 2, Juli 2015.

Jaya, Hendra. (2012). Pengembangan Laboratorium Virtual untuk Kegiatan Praktikum dan Memfasilitasi Pendidikan Karakter di SMK. Jurnal Pendidikan Vokasi. Vol. 2 Nomor 1, Februari 2012.

Kusnohadi. (2014). Pendidik Online: Perluasan Tugas dari Kelas Konvensional Menuju Kelas Maya. Jurnal TEKNODIK. Vol. 18, No. 3, Desember 2014. Jakarta: Pustekkom.

Larasati, D. S. dan Sukisno, M. (2014). Penggunaan Media Simulasi Berbasis Teknologi Informasi dalam Pembelajaran Fisika pada Siswa Lintas Minat di SMA Negeri 3 Pekalongan. Jurnal Unnes Physic education. Vol. 3, No. 3, 2014.

Muna, I. A. (2016). Optimalisasi Fungsi Laboratorium IPA melalui Kegiatan Praktikum pada Prodi PGMI Jurusan Tarbiyah STAIN 
Ponorogo. Kodifikasia. Vol. 10 No. 1.

Nirwana, Ratih Rizqi. (2011). Pemanfaatan Laboratorium Virtual dan E-Reference dalam Proses Pembelajaran dan Penelitian IImu Kimia. Jurnal PHENOMENON. Vol.1 No. 1, Juli 2011.

Nur, Hikmah, dkk. (2017). Penerapan Laboratorium Virtual untuk Meningkatkan Pemahaman Konsep siswa. Jurnal Kimia dan Pendidikan. Vol. 2 No. 2, Juli 2017.

Nurrokhmah. I., E., \& Sunarto, W. (2013). Pengaruh Penerapan Virtual Labs Berbasis Inkuiri terhadap Hasil Belajar Kimia. Journal Jurusan Kimia FMIPA. Vol. 2, No. 1.

Ponimin. (2010). Memadukan Laboratorium Nyata dan Maya Dengan Penugasan Siswa Berbasis Multimedia pada Pembelajaran Getaran dan Gelombang. JP2F. Vol. 2 No. 1 April 2010.

Rizki, J. W. S. (2013). Optimalisasi Fungsi Perpustakaan Perguruan Tinggi Melalui Peran Pustakawan. Jurnal Al-Kuttab. Vol. 1, No. 2.

Setiadi, R. \& Muflika, A. A. (2012). Eksplorasi Pemberdayaan Courseware Simulasi PhET untuk Membangun Keterampilan Proses Sains Siswa SMA. Jurnal Pendidikan Kimia. Vol 17, No. 2.

Siahaan, Sudirman. (2018). Perintisan Model Pembelajaran Terintegrasi TIK di Daerah Terdepan, Terluar, Tertinggal, dan Perbatasan. Jurnal TEKNODIK. Vol. 22, No. 2, Desember 2018. Jakarta: Pustekkom.

Subroto, Gatot. (2015). Peran dan Tantangan TIK (Internet) dalam Pembangunan Pendidikan Indonesia. Jurnal TEKNODIK. Vol. 19 Nomor 2, Agustus 2015. Jakarta: Pustekkom.

Sumargo, E. \& Yuanita, L. (2014). Penerapan Media Laboratorium Virtual (PhET) pada Materi Laju Reaksi dengan Model Pengajaran Langsung. Unesa Journal of Chemical Education.

Warsita, Bambang. (2019). Pemanfaatan Portal Rumah Belajar untuk Meningkatkan Kualitas Pembelajaran. Jurnal TEKNODIK. Vol. 23 Nomor 1, Juni 2019.

\section{Disertasi/Thesis/Skripsi}

Ekasari, R. (2016). Pengaruh Pengajaran Langsung (Direct Instruction) Berbantuan Media Laboratorium Virtual Terhadap Pengusaan Konsep Dan Kreativitas Fisika Peserta Didik. (Skripsi). Mataram: Universitas Mataram. Diakses dari http://fkipunram.rf.gd/ uploads/E1Q0 12048.pdf.

Ferreira, Sousa, Nafalski, Machotka, Nedic. (2010). Collaborative Learning Based on a Micro-Webserver Remote Test Controller. Bridgeport: University of South Australia.

Jasmadi. (2018). Penggunaan Media Virtual Laboratory dalan Pembelajaran Konsep Optik Geometri Di SMK Kesehatan Asy-Syifa School Banda Aceh. (Skripsi). Banda Aceh: Fakultas Tarbiyah dan Keguruan Prodi Pendidikan Fisika Universitas Islam Negeri Ar-Raniry Darusalam.

Rahmawati, Y. (2010). Perkembangan Sistem Pendidikan Balai Pondok Pesantren Pabelan (Menuju Pesantren Modern). (Skripsi). Semarang: Universitas Negeri Semarang.

\section{Lain-lain}

Biro Pusat Statistik. (2012). Statistik Kesejahteraan Rakyat 2012. Jakarta. Biro Pusat Statistik.

Hendrawati, Sri. (2012). Keterampilan Proses dan Implementasinya dalam Pembelajaran Sain Tingkat Sekolah Dasar. KPS, pembelajaran, Sains, SD.

Jagodzinski, P. \& Wolski, R. (2014). The Examination of the Impact on Students' Use of Gestures While Working in a Virtual Chemical Laboratory for their Cognitive Abilities. Problem of Education.

Pustekkom. (2017). Panduan Pemanfaatan Portal Rumah Belajar dalam Pembelajaran di Sekolah. "Strategi Pembelajaran Berbasis TIK Memanfaatkan Rumah Belajar". Jakarta: Pustekkom Kemendikbud. 
